\title{
ASSESSMENT OF COASTAL LAND USE CHANGES IN BANTEN BAY, INDONESIA USING DIFFERENT CHANGE DETECTION METHODS
}

\author{
PUVADOL DOYDEE ${ }^{1}$ AND VINCENTIUS SIREGAR ${ }^{2}$ \\ 'Department of Fishery Management, Faculty of Fisheries, Kasetsart University, \\ Bangkok, 10900, Thailand \\ ${ }^{2}$ SEAMEO BIOTROP, Jl. Raya Tajur Km 6, P.O Box 116, Bogor Indonesia E-mail:vincents@biotrop.org
}

\begin{abstract}
Many types of the coastal land use in Banten Bay have been assessed in order to know the change as evidently detected by Landsat imagery in 1994 and 2001. Image processing such as, supervised classification and various change detection techniques are performed to the satellite images. Red Green method showed the best result for detecting the coastal land use change. This method is suitable for detecting the increasing areas of the paddy fields and settlement. Image Differencing method is capable to detect the increasing areas in agriculture, decreasing in fishponds and natural areas. Image Ratioing method can be considered suitable for detecting the increasing area of fishponds, decreasing of paddy fields and agriculture areas. Each coastal land use type has increased, except for the natural area/brushwood. Most of agriculture and paddy fields areas have been converted to fish ponds.
\end{abstract}

Key words: coastal land use/land cover, change detection method, remote sensing

\section{INTRODUCTION}

As a transition area between land and sea, coast is characterized essentially by geologic nature of the land. Sometimes, coastal zone is defined depending on the project purposes, for example LOICZ project (Holligan and de Boois 1993). This zone in many cases is relatively unstable and fragile (Carter 1989), but became an important place for the human activities, such as culture, economic, fisheries, industry, tourism and social (Rais and de Boois 1997). More than $60 \%$ of the human population lives in coastal area and it will increase in the future, hi many cases, coastal area is the best place or the only available space for city development, agriculture, fisheries, industry and tourisms. This condition will cause the increasing demand for space for such activities. However, in coastal zone a land use change is obviously a phenomenon (LOICZ 1994; Williams et al 1997; NOAA 1998) This change is an essential matter that should be monitored for planning or avoiding any further changes that can damage or harm the environment. Remote sensing technique is one of the effective tools in monitoring phenomena that change continuously overtime and cover large areas (Aronoff 1991). One of the major applications of remote sensing technique is change detection method. Many readymade algorithms are available to perform that method. Despite of their differences in identification, an accurate spatial registration of the various dates of imagery is a requirement for all methods used.

Corresponding author: vincents@biotrop.org 122 
This study is intended to assess the capability of four methods of change detection in detecting the change in coastal land use, and to compare the result of those methods with each other. Location of this study is the coastal zone of Banten Bay.

Banten Bay is an area most frequently used for various researches, since in this region many activities are taken place, such as agriculture, fishing and mariculture, harbor, and industry. There is no doubt that these activities will influence the coastal habitats and resources.

\section{MATERIALS AND METHODS}

The study area is located in Banten Bay at the northern coast of Banten Province (Figure 1). Banten bay has an area of about $120 \mathrm{~km}^{2}$ with water depth of less than $13 \mathrm{~m}$. Geographically, this bay lies on $05^{\circ} 55^{\prime} \mathrm{S}-06^{\circ} 05^{\prime} \mathrm{S}$ and $106^{\circ} 05^{\prime} \mathrm{E}-106^{\circ} 15^{\prime} \mathrm{E}$ and the distance from Jakarta is about $175 \mathrm{~km}$. This bay is also characterized as a lowland area (Saptarini 2000).

Data used comprised satellite data of Landsat-5 TM (with the path/row 123/064 and acquisition date of April 6, 1994), and Landsat-7 ETIVT (with path/row 123/064 and acquisition date of August 7, 2001, NASA, 2002), topographic and geomorphological maps. Different software have been used such as image processing ER Mapper (ER Mapper 1997), Banten Bay Information System 3.0 and Geographic Information System.

Supervised classification method used has the objective to identify and classify the features in an image quantitatively (Richards 1995; Lillesand and Kiefer 1994; Congalton and Green 1999; Yusuf 2001). This involves the analysis of multi-spectral image and the application of statistically based decision rules for determining the coastal land use type of each pixel on an image (Middlekoop and Lif 1991).

Many different techniques have been developed for change detection. These methods involve change extraction and change classification. (Coppin et al. 2002; Jensen 1986). The use of change detection techniques in this study comprised four methods, including Red Green, Image Differencing, Image Ratioing and Principal Component Analysis methods. Image analysis was performed to assess the coastal land use change between two different dates by overlaying the images of Landsat-5 TM in 1994 and Landsat-7 ETM ${ }^{+}$in 2001, and applying the change detection techniques as stated above.

Prior to the application of change detection techniques, the images utilized have to be normalized using atmospheric correction technique of histogram adjustment in order to eliminate error due to different atmospheric conditions of the images of different periods (Wallace and Campbell 1996). Image of 1994 was rectified to image of 2001 which has been already corrected (Geodetic datum WGS 84 and Map projection SUTM 48). 


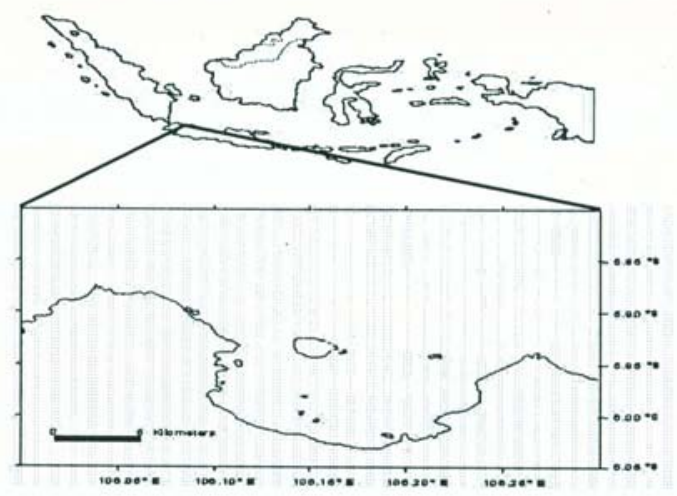

Figure 1. The study area in Banten Bay, Indonesia.

\section{RESULTS AND DISCUSSIONS}

\section{Coastal Land use in 1994 and 2001}

The type of coastal land use in 1994 and 2001 are grouped into 5 classes such as, paddy fields, fishponds, settlement, agriculture and natural areas (brushwood). The maps of coastal land use were prepared from the result of supervised classification using the band combination of 542/RGB (Figure 2.)
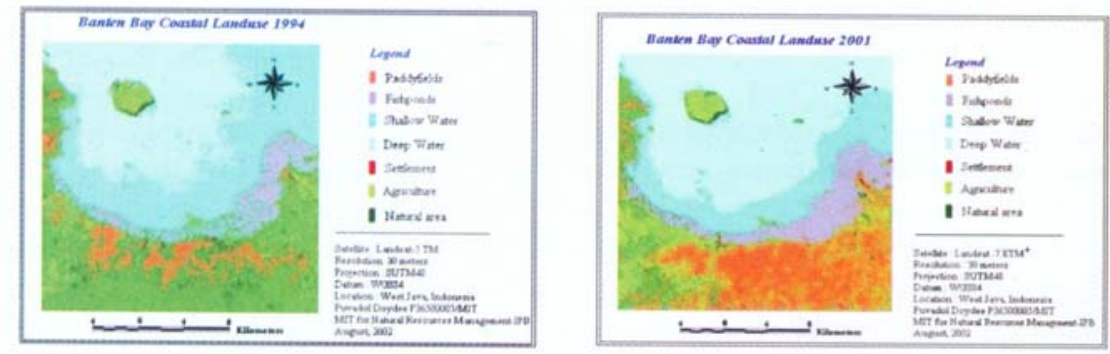

Figure 2. Land use types of Banten Bay in 1994 and 2001.

\section{Change Detection Techniques}

Red Green Method

This method involves displaying simultaneously one dataset in green and one dataset in red, namely image in 1994 was displayed as red and image in 2001 was displayed as green. The red color means that these areas only exist in image 1994 and the green color in image 2001. For example in Lontar district (Figure 3) as zoomed-in, paddy fields in 1994 have been converted to fishponds in 2001. The red color is represented as paddy fields before and those that have been converted into fishponds in 2001. This could be confirmed by using geomorphological map and thematic coastal land use map resulted from supervised classification. 


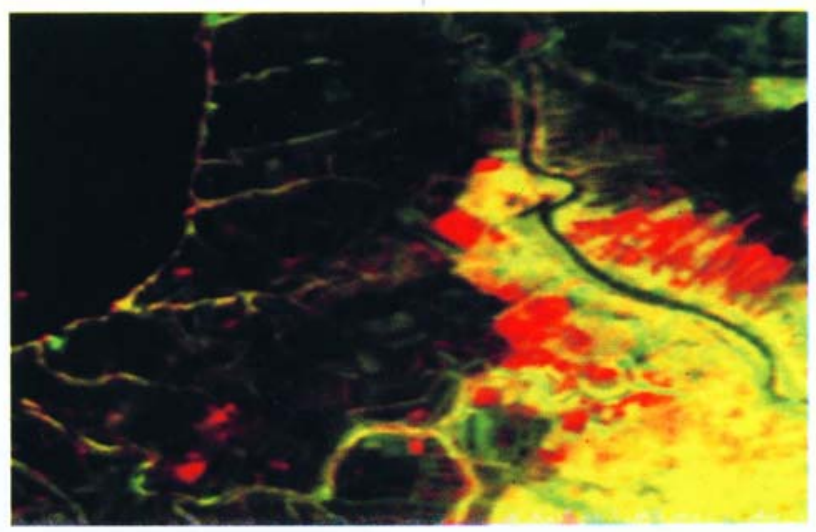

Figure 3. Result of red green method, yellow color indicates that the area is not converted

\section{Image Differencing Method}

The digital number value of image in 2001 was subtracted from digital number value of image in 1994. The basic concept of this method is that, in the raster data, each band has its digital value (DN). Therefore, if it is subtracted from the same DN value of each pixel in both images, the output is equal to 0 . The output might be minus or plus in the case that those pixels do not have the same DN values, this means that there is a change of value between the two images. This change might be due to the change of characteristic of the object. The output of this method was displayed as pseudo color area (Figure 4-left). Prior to data overlay, the raster data should be converted from raster cells into vector polygon and then overlaid that vector (change portion) with the original image so that the raster and vector polygon could be distinguished (original image), the result is presented in Figure 4 (right).
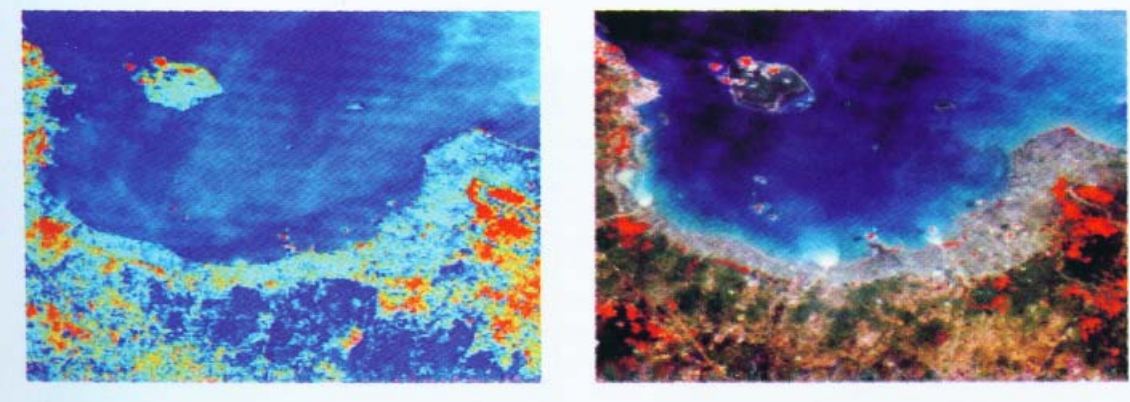

Figure 4. The result of image differencing method. 


\section{Image Ratioing Method}

Actually, this is a simple method as Image Differencing method where in this method the formula is changed from subtraction to division. The data from two registered images are divided pixel by pixel. Therefore, the areas in different dates that have the same value of DN is equal to 1 , it means that those areas do not change. Bands of TM1, TM2 and TM3 are highly correlated. The lower the correlation between two bands the greater the information content. Ratio of TM2 and TM5 provide some subtle wetland information (Jensen 1986). The result of this method is presented in Figure 5.
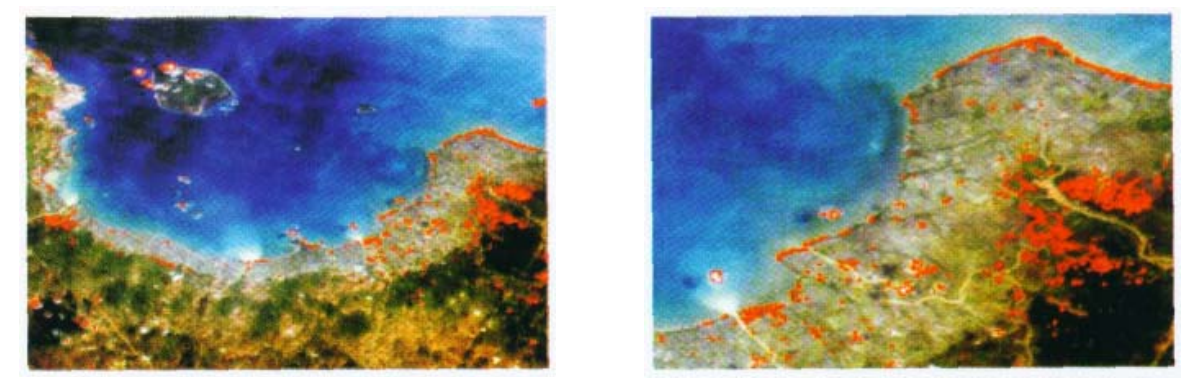

Figure 5. The result of

image ratioing method Principal Component Analysis Method

The PC\#2 has maximum variance of the original data set, therefore it is used for analysis. PC\#2 data consist of two bands inputs, where input 1 and input 2 were images of 1994 and 2001, respectively. The result showed that the bright blue color appears covering the areas (Figure 6-left). The output should be converted from raster cells into vector polygon in order to facilitate the interpretation (Figure 6right).
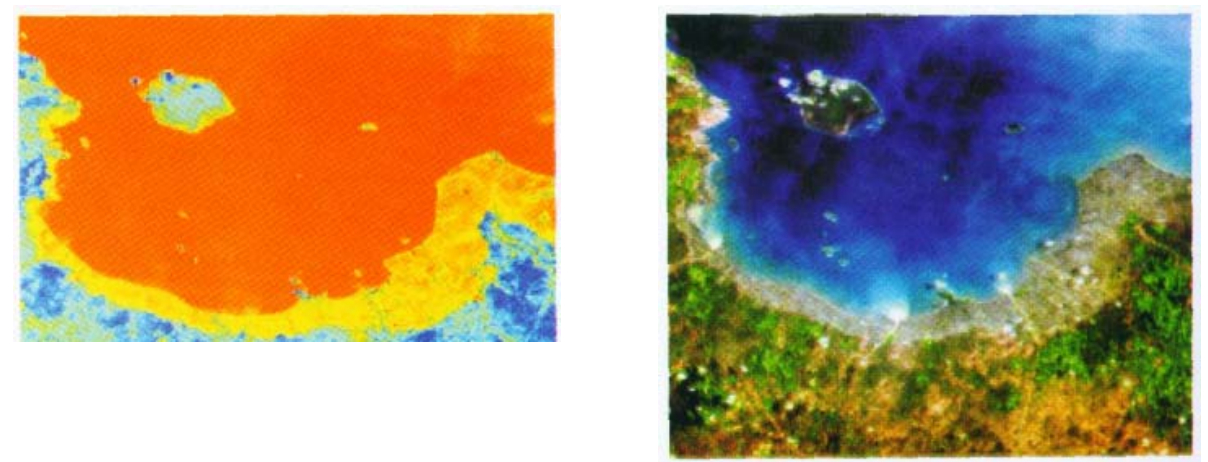

Figure 6. The result of principal component analysis method 


\section{Change Analysis}

The entire study area was 46785.69 ha consisting of 23437.26 ha terrestrial zone and 23348.43 ha water. The classification of coastal land use (type) between two dates was processed by post-supervised classification method (Cho 2000) and the result is presented in Table 1.

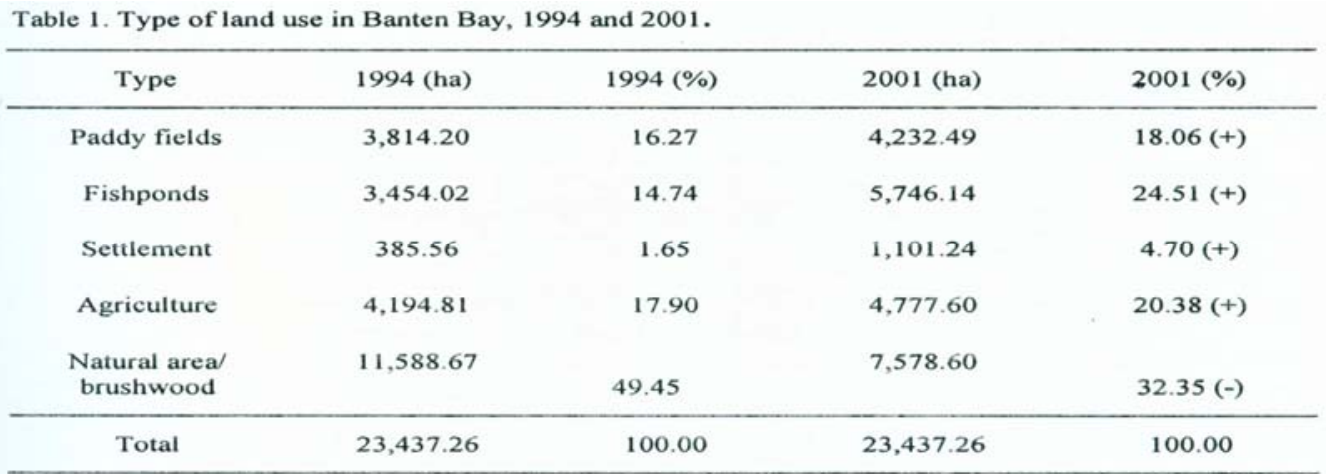

Table 1 shows that the area of each land use type has increased, except for the natural area/brushwood which shows the contrary. The main factor caused by this change is the increasing numbers of the population and human activities in this area. From the field check, it was observed that some parts of agriculture and paddy fields are converted into fishponds. It is known that in 1990's fishponds were very promising, and for that reason most of villagers and farmers converted their agriculture area and paddy fields into fishponds in the coastal zone.

According to Table 2, there are two types of changes, that is the increasing and the decreasing area. Obviously, the total areas of coastal land use converted was 7706.79 ha .These changes not only happen from one type of land use to other types, but also in the area of the same land use type. For example of decreasing area, it can be noted as follows: Paddy fields as in 1994 have been converted into different land use types, such as fishponds (812.46 ha), settlements (70.16 ha), and agriculture areas (712.66 ha), respectively in 2001. Fishponds as in 1994 have been converted only into settlement (8.15 ha) in 2001, while for settlement there is no change in terms of land use type and the area between the two periods. Agriculture as in 1994, has been converted into paddy fields (1015.06 ha), fishponds (761.39 ha) and settlement (317.18 ha), respectively in 2001. Natural areas (brushwood) in 1994 have been converted into paddy fields (998.51 ha), fishponds (727.27 ha), settlement (320.19 ha) and agriculture (1963.76 ha) in 2001. Meanwhile, the increasing areas of the land use types from 1994 to 2001 are as follows: Paddy fields are increased as 
much as 2013.57 ha from agricultural (1015.06 ha) and natural areas (998.51 ha); the area of fishponds are increased to 2301.12 ha from paddy fields (812.46 ha), agricultural (761.39 ha) and natural areas (727.27 ha); settlement areas are increased 715.68 ha which comprised paddy fields (70.16 ha), fish ponds (8.15 ha), agriculture (317.18 ha) and natural areas (320.19 ha) and; agriculture areas are increased to 2,676.42 ha that is from paddy fields 712.66 ha and natural areas about 1903.76 ha. The total of land use type (7706.79 ha) then is considered as a reference for selecting the best method of change detection to be applied.

Table 2. Coastal land use change between 1994 and 2001.

\begin{tabular}{cccccc|c}
\hline 2001 & $\begin{array}{c}\text { Paddy fields } \\
\text { (ha) }\end{array}$ & $\begin{array}{c}\text { Fishponds } \\
\text { (ha) }\end{array}$ & $\begin{array}{c}\text { Settlement } \\
\text { (ha) }\end{array}$ & $\begin{array}{c}\text { Agriculture } \\
\text { (ha) }\end{array}$ & $\begin{array}{c}\text { Natural area } \\
\text { (brushwood) }\end{array}$ & $\begin{array}{c}\text { Decrease } \\
\text { (ha) }\end{array}$ \\
\hline Paddy fields & $(2218.92)$ & $\mathbf{8 1 2 . 4 6}$ & 70.16 & 712.66 & None & $1,595.28$ \\
Fishponds & None & $(3445.87)$ & 8.15 & None & None & 8.15 \\
Settlement & None & None & $(385.56)$ & None & None & None \\
Agriculture & $1,015.06$ & 761.39 & 317.18 & $(2101.18)$ & None & $2,093.63$ \\
Natural area & 998.51 & 727.27 & 320.19 & $1,963.76$ & (7578.94) & $4,009.73$ \\
\hline Increase & $2,013.57$ & $2,301.12$ & 715.68 & $2,676.42$ & None & $7,706.79$ \\
\hline
\end{tabular}

Note: () the area which is not converted to other type of land use

Using the four converted detection methods, the converted areas of each method were as follows: the Red Green method (7094.97 ha), Image Differencing method (6185.25 ha), Image Ratioing method (8490.96) ha and Principal Component Analysis (PC\#2) (5920.47 ha), respectively. From the result presented in Table 3, it could be concluded that Red Green method is better for detecting the coastal land use change compared to other methods. Saptarini (2000) has also concluded that Red Green method is simple and easy method to detect the change of areas in coastal zone of Banten bay. This method shows that the total number of converted areas closely agrees with the number of converted areas of the reference.

Table 3 . The area change derived from four different change detection methods

\begin{tabular}{ccc}
\hline Change Detection Method & Area Change (ha) & Difference (ha) \\
\hline Red Green Method & $7,094.97$ & 611.82 \\
Image Differencing Method & $6,185.25$ & $1,521.54$ \\
Image Ratioing Method & $8,490.96$ & 784.17 \\
PCA Method (PC\#2) & $5,920.47$ & $1,786.32$ \\
\hline Reference change & & $7,706.79$ \\
\hline
\end{tabular}

As stated above, the total of each land use type has increased from 1994 to 2001, except for natural areas/brushwood which show the contrary. 
The increasing and decreasing areas of each type of land use were derived from four change detection methods. For increasing area in general, Red Green method is the best compared to the other methods. But, if the increasing area of each type of land use is observed, we found that only PC\#2 has no land use types which has a wide close to the reference (Table 4). It means that each change detection method is suitable to detect certain land use type.

Table 4. The increasing area of each land use type using the four change detection methods compared to the reference.

\begin{tabular}{llllll}
\hline Type & Red Green & Image Differencing & Image Ratioing & PC\#2 & References \\
\hline Paddy fields & $1,969.86$ & $1,680.39$ & $2,088.15$ & $1,802.88$ & $2,013.57$ \\
Fishponds & $2,161.82$ & $1,806.74$ & $2,394.97$ & $1,988.55$ & $2,301.12$ \\
Settlement & 804.84 & 439.41 & 827.13 & 493.20 & 715.68 \\
Agriculture & $2,158.44$ & $2,258.72$ & $3,180.70$ & $1,635.85$ & $2,676.42$ \\
\hline Total & $7,094.97$ & $6,185.25$ & $8,490.96$ & $5,920.47$ & $7,706.79$ \\
\hline
\end{tabular}

Therefore, it could be concluded that Red Green method is suitable for detecting the increase of paddy fields and settlements. Differencing method is better in detecting the increasing agriculture areas. Meanwhile, the Ratioing method could be considered as the best method to detect the increasing fishpond areas (Table 5).

Table 5. The difference (increasing) of area change calculated by four change detection methods used and the reference

\begin{tabular}{ccccc}
\hline \multicolumn{5}{c}{ Area Difference (ha) } \\
\hline Type & Red Green & Image Differencing & Image Ratioing & PC\#2 \\
\hline Paddy fields & 43.71 & 333.18 & 74.58 & 210.69 \\
Fishponds & 139.30 & 494.38 & 93.85 & 312.57 \\
Settlement & 89.16 & 276.27 & 111.45 & 222.48 \\
Agriculture & 517.98 & 417.70 & 504.28 & $1,040.57$ \\
\hline
\end{tabular}

For decreasing areas, all the change detection methods used showed that the area of each type of land use is far less under the area of reference (Table 6).

Table 6. The area change provided by four change detection methods

\begin{tabular}{cccccc}
\hline Type & Red Green & Image Differencing & Image Ratioing & PC\#2 & References \\
Paddy fields & 294.84 & 270.82 & 387.45 & 278.92 & $1,595.28$ \\
Fishponds & 486.80 & 397.17 & 694.27 & 464.59 & 8.15 \\
Agriculture & 483.42 & 849.15 & $1,480.00$ & 111.89 & $2,093.63$ \\
Natural area & $5,829.93$ & $4,668.11$ & $5,929.25$ & $5,065.07$ & $4,009.73$ \\
\hline Total & $7,094.97$ & $6,185.25$ & $8,490.96$ & $5,920.47$ & $7,706.79$ \\
\hline
\end{tabular}

Meanwhile, if the decreasing area of each type of land use provided by the change detection methods used is compared with the reference, it could be 
concluded that Image Differencing method is better for detecting the decreasing area of fishponds and natural areas compared with other methods and image Ratioing method could be considered as the better method for monitoring the decrease of paddy fields and agriculture areas (Table 7).

Table 7. The difference of area change (decreasing) for each land use type.

\begin{tabular}{lcccc}
\hline \multicolumn{5}{c}{ Difference of Area Change( Decreasing) (ha) } \\
\hline \multicolumn{1}{c}{ Items } & Red Green & Image Differencing & Image Ratioing & PC\#2 \\
\hline Paddy fields & $1,300.44$ & $1,324.46$ & $1,207.83$ & $1,316.36$ \\
Fishponds & 478.65. & 389.02 & 686.12 & 456.44 \\
Agriculture & $1,610.22$ & $1,244.48$ & 613.63 & $1,981.74$ \\
Natural area & $1,820.20$ & 658.38 & $1,919.52$ & $1,055.34$ \\
\hline
\end{tabular}

This study showed that no specific change detection method could be used to detect all land use types. Each method could detect better a specific land use type compared to the other methods.

\section{CONCLUSIONS}

Supervised classification of remotely sensed data (Landsat data in!994 and 2001) of the coastal zone of Banten Bay provides 5 land use types such as paddy fields, fishponds, agricultural area, settlement and brushwood (natural area). These land use types served as the reference for land use change during those two periods. To detect the change of land use types in those areas, several change detection methods are performed to the Landsat satellite data.

Change analysis showed that among various change detection methods used, the Red Green method has provided the best result for detecting the coastal land use change. This method is suitable for detecting the increasing areas of the paddy fields and settlements. Meanwhile, Image Differencing method is capable to detect increasing areas in agriculture, decreasing in fishponds and natural areas. Image Ratioing method could be considered suitable for detecting the increasing area of fishponds, decreasing of paddy fields and agriculture. Each coastal land use type in the study areas had increased, except for the natural areas, and most of agriculture and paddy fields areas have been converted to fishponds. Certain change detection methods used has shown a good performance for detecting the change of certain coastal land use types in Banten bay, however, several tests in different areas are needed to be conducted in order to know the level of accuracy of each method used.

\section{ACKNOWLEDGMENTS}

The authors would like to acknowledge the funding support of the SEAMEO Regional Center for Graduate Study and Research in Agriculture (SEAMEO SEARCA), and technical support and assistance of Mr. Nyoman Sukmantalya in providing all the data needed. 


\section{REFERENCES}

Aronoff, S. 1991. Geographic Information Systems. A Management Perspective, WDL Publications,

Cultural Ottawa, 294 p. Carter, R.W.G. 1988. Coastal Environment. An Introduction to the Physical, Ecological and

Systems of Coastlines, Academic Press, Toronto, 617 p. Cho, S.H.2000. Digital Change Detection by Post-

classification Comparison of Multi-temporal Remotely

sensed data. University of Idaho, Departement of forest resources. Journal of the Korean

Society of Remote Sensing col 16, No 4, p. 367-373. www.ksrs.or.kr/iournal full/1 6-

Principles and

4\%20ftp/8josung.pdf Congalton, R. G. and K. Green. 1999. Assessing the Accuracy of Remotely Sensed Data:

Digital change detection methods in natural

ecosystem monitoring. In Analysis of Multi-temporal remote sensing images. Bruzzone,L.and

Smiths,P.eds. World Scientific, New Jersey. 440 p. ER Mapper 5.5 .1997. ER Mapper Workbook - level One,

Training Workbook, 25 August 1997,

California, 382 p. Holligan, P.M. and H. de Boois. 1993. Land-Ocean Interactions in the Coastal Zone

(LOICZ). Global

Change Report (25). IGBP. Stockholm, 50 p, URL: http:// wwlv,

cs.utk. edu/ l ucas/nubl icat ions/publ ications, html Jensen, J.R. 1986 Introductory Digital Image Processing. A

Remote Sensing Perspective. Prentice-Hall, Edition), John

Englewood Cliffs, 318 p. Lillesand T. M. and R. W. Kiefer .1994. Remote Sensing and Image Interpretation (3 rd

International Geosphere

Biosphere Programme of the International Council of Scientific Unions, p. 6. Middelkoop, H. and J. Lif. 1991.

Implemention on temporal relationship in: Knowledge Base System of

satellite image, Photogrammetric Engineering and Remote Sensing. Vol.57, July 1991, p. 937-

945. NASA .2002. Landsat 7 Science Data Users Handbook, URL: http://tpwww.gsfc. nasa.gov/IAS/handbook/handbook_htmls/chapter8/chapter8.html

NOAA .1998. Shoreline, Coastal zone Glossary, URL: http://www.csc.noaa.gQv/ sho reline/glossarv.html Rais, J., Dutton,

M., Pantimena, L., Plouffe, J. and R. Dahuri, 1997. Integrated Coastal and Marine

Resource Management, Proceedings of International Symposium, 25-27 November 1997,

Batu, ITN, BAKOSURTANAL and Proyek Pesisir, Malang. p. 273-276. Richards, J.A. 1995. Remote Sensing

Digital Image Analysis, Springer- Verlag, Berlin, p. 54-57. Saptarini, D. 2000. Coastline changes detection using remote

sensing technique: Banten Bay study case,

Master in Information Technology for Natural Resources Management, Bogor Agriculture

University (1PB), Bogor, 53 p. Wallace, J. and N. Campbell. 1996 Evaluation of the Feasibility of Remote

Sensing for Monitoring,

National State of the Environment Indicators, Technical Paper Series, Department of the

Environment, Canberra, p. 30. Williams, S.J., K. Dodd K, and K.K. Gohn .1997. Coast in Crisis, USGS

Homepage. URL:

http://www.usgs.gOv/http://www.usgs.gov/Yusuf, D.N. 2001. Remote Sensing and GIS for Landuse Change

Analysis, Case study in Kab. Bandung,

Master in Information Technology for Natural Resources Management, Bogor Agriculture

University (IPB), Bogor, 68 p. 